\title{
Appraisal of Biogas Potential of Biogas from Animal Dung in Saeedabad, Pakistan
}

\author{
AMJAD ALI SHAH*, AND ABDUL RAZAQUE SAHITO* \\ RECEIVED ON 11.11.2016 ACCEPTED ON 21.02.2017
}

\begin{abstract}
Pakistan is facing energy scarcity. The biogas is one of the renewable substitutes. It does not only overcome the energy scarcity but also harness the energy from animal dung which causes the $\mathrm{CO}_{2}$ emissions. The present study was done on the appraisal of potential of biogas from the dung of animals (Buffaloes, Cows, Goats and Sheep) within the villages surrounded by Taluka Saeedabad. The purpose of the study was the energy potential of the biogas and the selection of the most suitable design and size of the biogas plant for the villagers. The present study also includes the domestic biogas plant economics. As per the estimation, total quantity of animal dung generated was about 129 tons/day, which can produce $3859 \mathrm{~m}^{3}$ of biogas per day. On the contrary, for cooking villagers require only $2748 \mathrm{~m}^{3}$ of biogas per day. Moreover, the surplus biogas of $1111 \mathrm{~m}^{3}$ per day can be used to produce electricity of $6666 \mathrm{kWh}$ per day, which can fulfill the demand of about half of the population of villages under study. People are using firewood, cotton stalks, kerosene oil and LPG (Liquefied Petroleum Gas) for cooking. Converting animal dung into the biogas not only reduces the consumption of the traditional fuels used (Firewood, Cotton Stalks, Kerosene Oil and LPG), but also prevents about 900 thousand tons of $\mathrm{CO}_{2}$ emissions into the environment. Additionally, a fixed dome biogas plant of 8-10 $\mathrm{m}^{3}$ size was recommended for each of the houses under study.
\end{abstract}

Key Words: Quantification of Animal Dung, Biogas Potential, Biogas Required, Design of Biogas Plant.

\section{INTRODUCTION}

1

nergy issues are being faced by Pakistan since last decade. Pakistan spent approximately US\$ 7000 million in 2007 and US\$ 12000 million in 2011 annually on energy source to meet its demands [1]. Pakistan is a $24^{\text {th }}$ international country in production of natural gas. Annually, it produces around 43000 million $\mathrm{m}^{3}$ of natural gas [2]. From last decade, natural gas has been used in 3.7 million vehicles. On the basis of consumption of the natural gas in vehicles, Pakistanis ranked as $2^{\text {nd }}$ country in the world [3]. Pakistan has great potential of renewable energy resources such as wind, solar, geothermal and hydropower energy. But these sources are expansive. Biogas is one type biofuel, which is a better substitute in comparison to the other renewable energy sources. It is a combination of gases received from the breakdown of organic compound such as animal dung, crop and their residue, food yard waste, sewage waste and municipal solid waste. The process of breakdown of the organic matter is also known as fermentation [4].

* Institute of Environmental Engineering \& Management, Mehran University of Engineering \& Technology, Jamshoro.

Mehran University Research Journal of Engineering \& Technology, Volume 36, No. 3, July, 2017 [p-ISSN: 0254-7821, e-ISSN: 2413-7219] 
The biogas is produced in an anaerobic digester without the presence of oxygen. It is obtained through three staged biochemical process, i.e. hydrolysis, acidification and methanogensis. An important element of biogas is methane, which is about 56-70\%, followed by carbon dioxide of about 21-40\%. Biogas also contains some traces of hydrogen, Sulfur dioxide, ammonia, nitrogen and water vapor [5-6]. According to Pakistan livestock census [7], cows and buffaloes are about 0.07 billion, goats and sheep are more than 0.09 billion in numbers. From the waste of these animals, about 20 billion $\mathrm{m}^{3}$ of biogas can be produced annually through the installation of about 5 million domestic biogas plants. Out of the 5 million domestic biogas plants, only 6000 plus are working in Pakistan [7]. The biogas technology is not new in Pakistan, in 1959 the local people used animal manure and generated biogas for cooking in Sindh. In 1974 Pakistan government started a program of biogas plants in the country and 4137 biogas plants were installed in Pakistan in three phases [8]. The biogas is a serious solution of greenhouse gas emissions and reduces the carbon and methane gas emissions from cake of dung [4].

The study area selected for the present work was the villages, surrounded by Taluka Saeedabad, District Matiari, Pakistan. More than $80 \%$ population of Saeedabad lives in the rural areas of the city and for cooking they are depending upon biomass energy including wood fuel and crop residues. The burning of biomass has serious effects such as degradation of the environment, deforestation, different health problems for women and children like lung and eye diseases. Moreover, the burning of the biomass is the major source of greenhouse [9-10]. As per the estimation, the burning of the solid fuel may be responsible for 0.8-2.4 million premature deaths each year [11].
The main objective of the present study was the energy potential of the animal and the design of the most suitable size and type of biogas plant for the villagers of Taluka Saeedabad.

\section{MATERIALS AND METHOD}

\subsection{Questionnaire Survey of the Study Area and Data Analysis}

To acquire the data from field survey, a questionnaire was designed, and the field survey of villages surrounded by the Saeedabad was carried out. The questionnaire contains blanks for data including, no of persons residing in each home, the population of each animal species, type of animal regarding their source of foodstuff (i.e. either grazing or non-grazing), existing use of animal dung, existing quantity and type of fuel used for cooking purpose. The field survey was carried out in 23 villages in Taulka Saeedabad. Additionally, the dung of each specie was measured using electronic balance.

The data obtained from the questionnaire was analyzed by the weighted average method [12]. Moreover, Equation (1) was designed for a population of villagers:

$\mathrm{P}=\sum_{\mathrm{i}=1}^{\mathrm{m}} \mathrm{P}_{\mathrm{hi}} \times \mathrm{Hv}_{\mathrm{i}}$

Where $\mathrm{P}$ is human population in all villages, $\mathrm{P}_{\mathrm{h}}$ is human population in a house, $\mathrm{Hv}$ is the number of houses in the village and i represent no of the house for m number of houses. The Equation (2) was designed for population of animals in all the villages surrounded by Saeedabad.

$\mathrm{A}=\sum_{\mathrm{i}=1}^{\mathrm{m}} \mathrm{Hv}_{\mathrm{i}}\left(\mathrm{B}_{\mathrm{i}}+\mathrm{C}_{\mathrm{i}}+\mathrm{G}_{\mathrm{i}}+\mathrm{S}_{\mathrm{i}}\right)$

Where $\mathrm{A}$ is the number of animals in all villages, $\mathrm{B}$ is the number of Buffaloes in a house, $\mathrm{C}$ is the number of Cows

Mehran University Research Journal of Engineering \& Technology, Volume 36, No. 3, July, 2017 [p-ISSN: 0254-7821, e-ISSN: 2413-7219] 
in a house, $\mathrm{G}$ is the number of Goats in a house and $\mathrm{S}$ is the number of Sheep in a house. The Equation (3) was developed to calculate the total quantity of dung from all animals in all villages.

$\mathrm{TD}=\sum_{\substack{\mathrm{j}=1 \\ \mathrm{k}=1,2}}^{\mathrm{n}}\left(\mathrm{DPB}_{\mathrm{k}} \times \mathrm{Bv}_{\mathrm{i}}\right)+\left(\mathrm{DPC}_{\mathrm{k}} \times \mathrm{Cv}_{\mathrm{i}}\right)+\left(\mathrm{DPG}_{\mathrm{k}} \times \mathrm{Gv}_{\mathrm{i}}\right)+\left(\mathrm{DPS}_{\mathrm{k}} \times \mathrm{Sv}_{\mathrm{i}}\right)$

Where TD is the total quantity of dung from all animals in all villages in $\mathrm{kg}, \mathrm{Bv}$ is the number of Buffaloes in villages, $\mathrm{Cv}$ is the number of Cows in villages, $\mathrm{Gv}$ is the number of Goats in villages, Sv is the number of Sheep in villages, DPB is the production of dung per Buffalo, DPC is production of dung per Cow, DPG is production of dung per Goat and DPS production of dung per Sheep. Moreover, the $\mathrm{j}$ represents a village and $\mathrm{n}$ represents the total number of villages, whereas $\mathrm{k}$ represents the type of animal either grazing $(k=1)$ or non-grazing $(k=2)$. The Equation (4) was developed for existing uses of dung in the selected villages.

$$
\mathrm{UD}=\sum_{\mathrm{j}=1}^{\mathrm{n}} \mathrm{TD}_{\mathrm{j}}\left(\mathrm{CH}_{\mathrm{j}}+\mathrm{DU}_{\mathrm{j}}+\mathrm{FO}_{\mathrm{j}}\right)
$$

Where UD is existing use of dung in villages in $\mathrm{kg}, \mathrm{CH}$ represents the fraction of animal dung used for cooking/ heating in terms of percentage, DU represents the fraction of animal dung dumped as the waste in terms of percentage and FO represents the fraction of animal dung used as organic fertilizer in terms of percentage.

The biogas potential and biogas required was calculated on the bases of methane potential in one kilogram of dung from the literature review. Equation (5) was developed to calculate biogas potential from animal dung for each village.

$$
\mathrm{PB}=\sum_{\mathrm{j}=1}^{\mathrm{n}} 0.03 \times \mathrm{TD}_{\mathrm{j}}
$$

Where PB is potential of Biogas in $\mathrm{m}^{3}$, and the constant digit is the specific biogas, which was obtained from the literature as one $\mathrm{kg}$ of dung produces biogas of $0.03 \mathrm{~m}^{3}$ [13]. Then, an Equation (6) was designed through which biogas required is calculated each village.

$$
\mathrm{BR}=\sum_{\mathrm{j}=1}^{\mathrm{n}} 0.26 \times \mathrm{P}_{\mathrm{j}}
$$

Where BR is biogas required in $\mathrm{m}^{3}$, and the constant digit is the specific quantity of biogas required by a person/day. A specific quantity of biogas required by a person/day was obtained from literature as $0.26 \mathrm{~m}^{3}$ [14]. Equation (7) was developed to calculate existing fuel used in the villages or sources of energy used for the cooking.

$\mathrm{FU}=\sum_{\mathrm{j}=1}^{\mathrm{n}} \mathrm{P}_{\mathrm{j}}(\mathrm{CF}+\mathrm{CC}+\mathrm{CK}+\mathrm{CLPG}) \mathrm{R}$

Where FU is existing fuel used in villages, CF is Consumption of Firewood/head, CC is Consumption Cotton stalks/head, CK is Consumption Kerosene Oil/ head, and CLPG is Consumption LPG/head. The cost of firewood, cotton stalks and kerosene oil was different in different villages, but the cost of the LPG was same. Equation (8) was developed to estimate the cost of fuel used in villages.

$\mathrm{FP}=\sum_{\mathrm{j}=1}^{\mathrm{n}}\left(\mathrm{PF}_{\mathrm{j}} \times \mathrm{CF}\right)+\left(\mathrm{PC}_{\mathrm{j}} \times \mathrm{CC}\right)+\left(\mathrm{PK}_{\mathrm{j}} \times \mathrm{CK}\right)+(\mathrm{PLPG} \times \mathrm{CLPG})$

Where FP is the price of fuel, $\mathrm{PF}$ is the price of firewood/ $\mathrm{kg}, \mathrm{PC}$ is the price of cotton stalks $/ \mathrm{kg}, \mathrm{PK}$ is the price kerosene oil/liter and PLPG is the price of LPG/kg.

\section{RESULTS AND DISCUSSION}

\subsection{Population of Villagers}

Total 650 houses were surveyed during the field study. Approximately, $80 \%$ of houses of each village were 
visited and interviews were conducted. Population of different villages surrounded by Saeedabad is shown in

Fig. 1. The population of 23 villages was 10594 persons and average population in each house was 9 persons. Moreover, the majority of the population was illiterate and jobless and their whole life depends upon livestock and agriculture. The livestock alone generates about $55 \%$ of their annual income through selling milk and animals.

\subsection{Population of Animals}

The population of animals was obtained from the questionnaire survey and represented for each village, buffaloes, cows and goats were present in all villages. The sheep were present only in 6 villages including Rajab Zardari, Achi Masjid Rahu, Usman Rahu, H. Rozi Domki, Pathan Sand and Haji Mazhar Shahani as shown in Fig. 2. Total quantity of buffaloes, cows, goats and sheep in selected villages were 4026, 2944, 8780 and 1793, respectively. The quantity of buffaloes, cows, goats and sheep in Pakistan are more than 23, 22, 49 and 24 million [15]. As compared to total animals in Pakistan, the quantity of animals in the selected villages is very low, but still significant in terms of domestic energy supply and environmental point of view.

\subsection{Measurement of Animal Dung}

The mass of animal dung (Buffalo, Cow, Goat and Sheep) was measured by using an electronic balance for samples of all four-animal species and collected for a week. Samples of animal dung were divided into two categories, i.e. grazing and non-grazing. The Fig. 3 show weights of different animal dung, based on the grazing and nongrazing animals.

The quantity of the dung of the non-grazing animals was higher than to the grazing animals. The highest quantity of the dung produced was from the buffalo i.e. $32 \mathrm{~kg} /$ day followed by $15,0.72$ and $0.48 \mathrm{~kg} /$ day for cow, sheep and goat, respectively. On the other hand, grazing buffalo, cow, sheep and goat generates dung of 23, 11, 0.54 and $0.36 \mathrm{~kg} /$ day, respectively. These results are comparable with the literature that the quantity of the animal was ranging from $0.37-0.38 \mathrm{~kg} /$ day for goat [16], $19-28 \mathrm{~kg} /$ day for buffalo [17], about $10 \mathrm{~kg}$ by cow [18] and 1.8-2 kg/day for sheep [19]. During the field survey, it was also

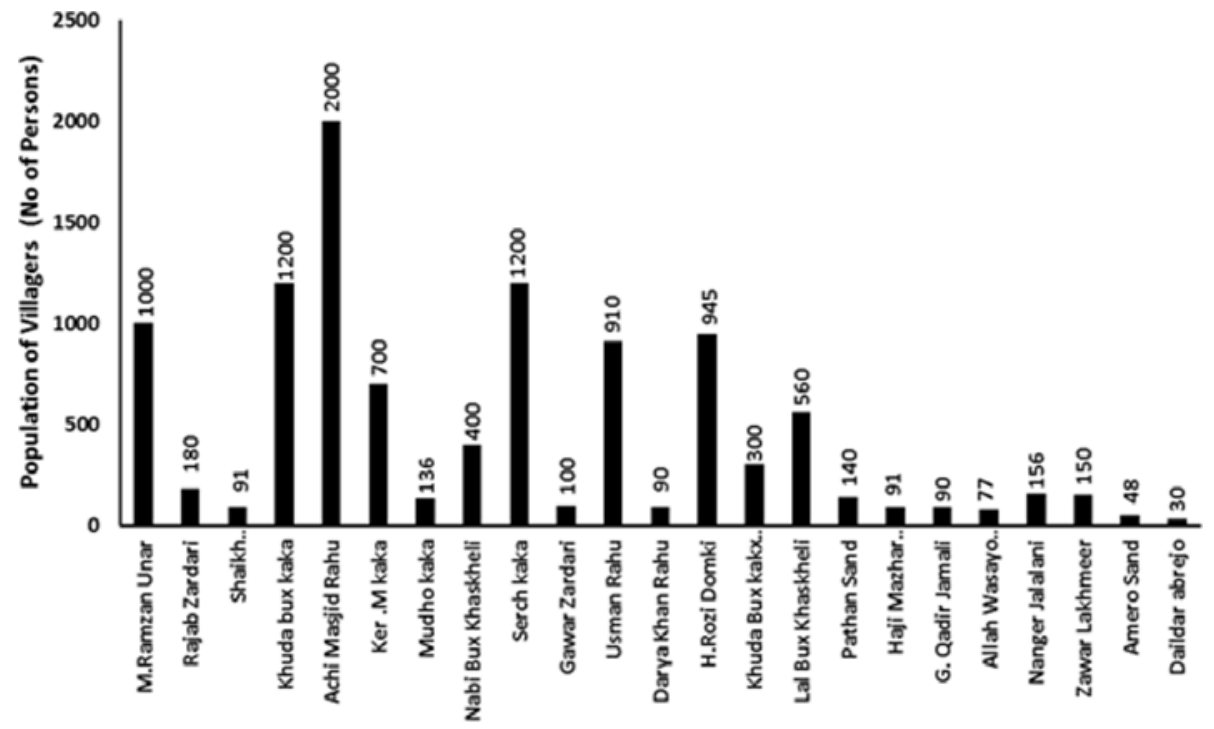

FIG. 1. POPULATION OF DIFFERENT VILLAGES SURROUNDED BY SAEEDABAD 
observed that about $90 \%$ of animals were grazing and only $10 \%$ were non-grazing, thus for the research work the minimum quantity of the animal dung was encountered (i.e. for grazing animals).

\subsection{Quantity of Animal Dung}

Total quantity of dung of animals from buffaloes, cows, goats and sheep produced in all villages were in the order of 92.5, 32.4, 3.2 and 0.86 tons/day, respectively as shown in Fig. 4. The total quantity of dung of all four species in all the villages was 129 tons/day. Buffaloes have good quantity of dung, followed by cows, whereas the quantity of the dung from goat and sheep was considerably low.

\subsection{Existing Uses of Animal Dung}

The existing use of the animal dung is shown in Fig. 5. From the field survey, it was observed that the villagers

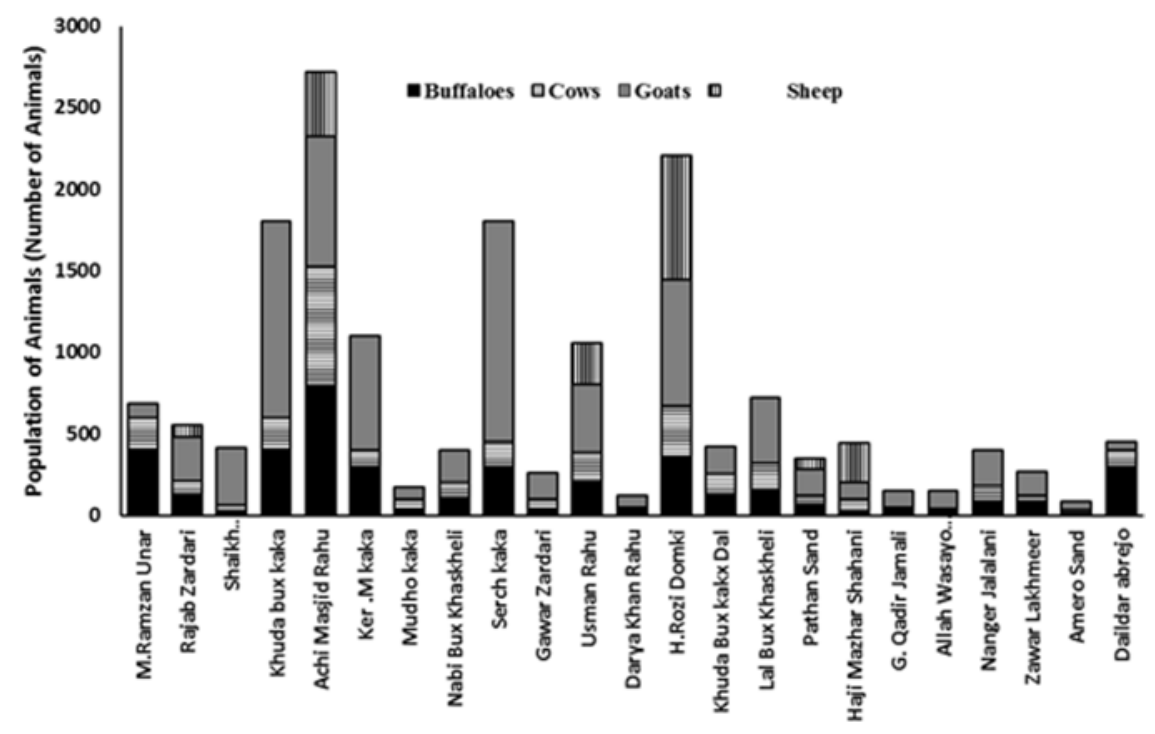

FIG. 2. POPULATION OF ANIMALS (BUFFALOES, COWS, GOATS AND SHEEP) IN ALL VILLAGES

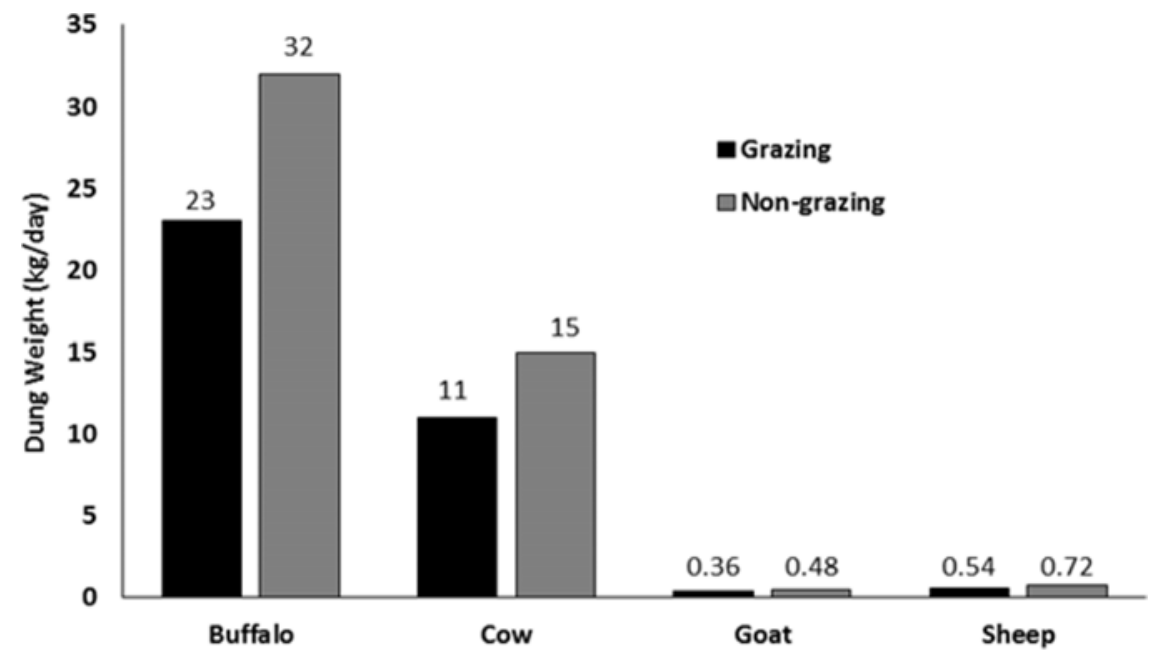

FIG. 3. MASS OF THE DUNG OF GRAZING AND NON-GRAZING ANIMALS 
near Saeedabad are using animal dung mainly for cooking, heating and as the organic fertilizer, while remaining dung is being wasted without any use. As per the results of the field survey, it was assessed that out of the total quantity of the animal dung produced, about $30 \%$ is being used as the fuel for cooking and heating, $46 \%$ is being used as organic fertilizer, while the remaining $24 \%$ is being dumped outside the villages. To get rid of the quantity of the dung that is dumped outside the villages, dung piles are sometimes burnt. As per the estimation, the quantity of the animal dung used as organic fertilizer, used for cooking and heating, and dumped as waste was 58, 40 and 31 tons/day, respectively.

\subsection{Biogas Potential and Required for Cooking}

The biogas potential from animal dung and biogas required for cooking were estimated for each village as shown in Fig. 6. As per the estimation from the quantity of the animal dung, it was observed that the large quantity of dung is produced from buffalos and cows, whereas only $3 \%$ is produced from the goats and sheep. Also, from the literature, it was observed that each kilogram of fresh animal dung produces about $0.03 \mathrm{~m}^{3}$ of biogas [13]. The Equation (5) was used to estimate the biogas potential available if the total quantity of the dung is utilized to convert it into the biogas. On the contrary, the quantity of the biogas required by each village was estimated through Equation (6), where it was considered that a person utilizes $0.26 \mathrm{~m}^{3}$ of biogas in a day [14].

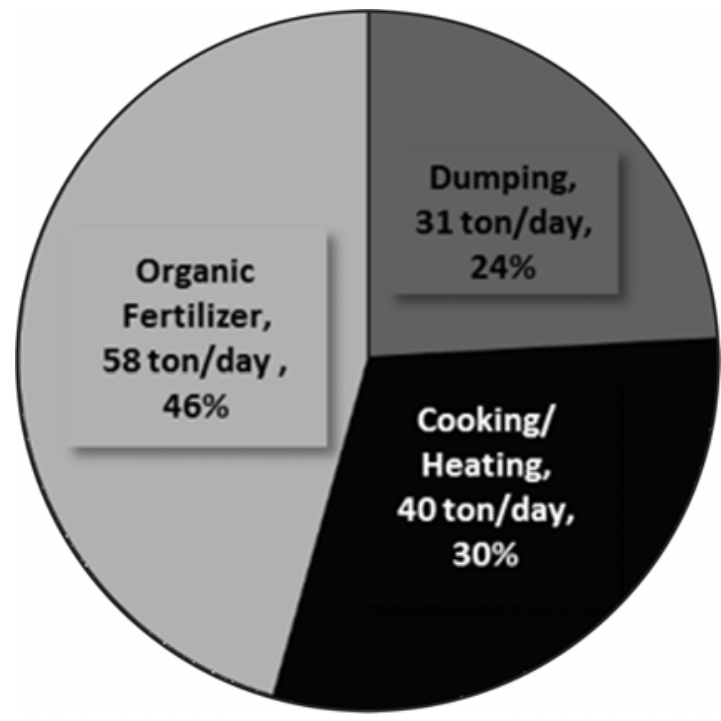

FIG. 5. EXISTING USES OF ANIMAL DUNG

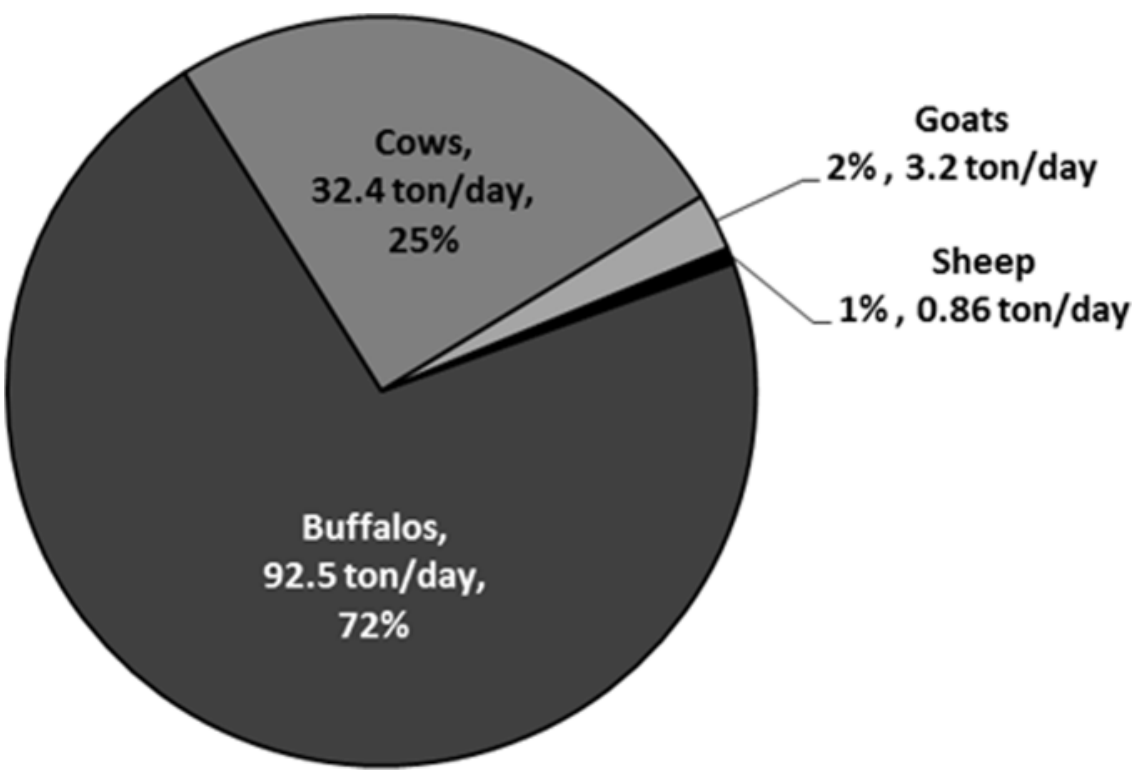

FIG. 4. QUANTITY OF DUNG OF BUFFALOES, COWS, GOATS AND SHEEP IN ALL VILLAGES

Mehran University Research Journal of Engineering \& Technology, Volume 36, No. 3, July, 2017 [p-ISSN: 0254-7821, e-ISSN: 2413-7219] 
It was observed that the quantity of the biogas that can be produced is higher than to the quantity of the biogas required for the cooking in each village, except the two villages i.e. Serach Kaka and Usman Rahu. The biogas potential in the villages was in the range of $12-804 \mathrm{~m}^{3} /$ day, whereas the biogas required was ranging from 8-520 $\mathrm{m}^{3} /$ day. The total biogas potential in all the villages was $3859 \mathrm{~m}^{3} /$ day, whereas the requirement for cooking was only $2748 \mathrm{~m}^{3}$ /day. Moreover, $1 \mathrm{~m}^{3}$ of biogas could produce $6 \mathrm{kWh}$ of electricity [20] and the surplus $1111 \mathrm{~m}^{3} /$ day of biogas can be used to produce electricity of $6666 \mathrm{kWh} /$ day. Meanwhile, the average electricity consumption in Pakistan is $439 \mathrm{kWh} /$ person/year [21], which is equivalent to $1.2 \mathrm{kWh} /$ person/day. Thus, the electricity produced from the surplus biogas can fulfil the demand of half of the population of the villagers in the area of study.

\subsection{Energy Resources Used by the Villages for Cooking}

From the field survey collected data, it was observed that the villagers were also using fire wood, cotton stalk, LPG and kerosene oil for cooking as shown in Fig 7. Firewood and cotton stalk were readily available, where as the LPG and kerosene oil were not easily available in the village and are being purchased from the Saeedabad city. For consumption of each source of fuel used for cooking, some houses from each village were selected randomly and their fuel consumption was estimated. In order to get the specific consumption of each fuel per person per day, the total energy consumption was divided by the total family members of a selected house. As per the results, the average consumption of firewood per person was about $22 \mathrm{~kg} / \mathrm{month}$, followed by 8-10 kg/month cotton stalks, 0.25 liter $/$ month of kerosene oil and $0.20 \mathrm{~kg} / \mathrm{month}$ of LPG. The average consumption of firewood per person in the Bhogteni village of Nepal was about $52.2 \mathrm{~kg} /$ month [22] and almost 180 kg/month in northeastern Himalaya India [23]. The lower consumption of the firewood used in the selected villages of the Taluka Saeedabad was because of the use of other sources of the fuel including cotton stalks, LPG and animal dung. The highest quantity of fuel other than animal dung was firewood, which is being consumed at the rate of 249 tons/month, followed by 102 tons/month of cotton stalks. On the other hand, the quantity of the kerosene oil and LPG was very low as 1402 liters/month and 0.2 tons/month, respectively. The main reasons of the lower consumption of the kerosene oil and LPG were higher cost and not easily available.

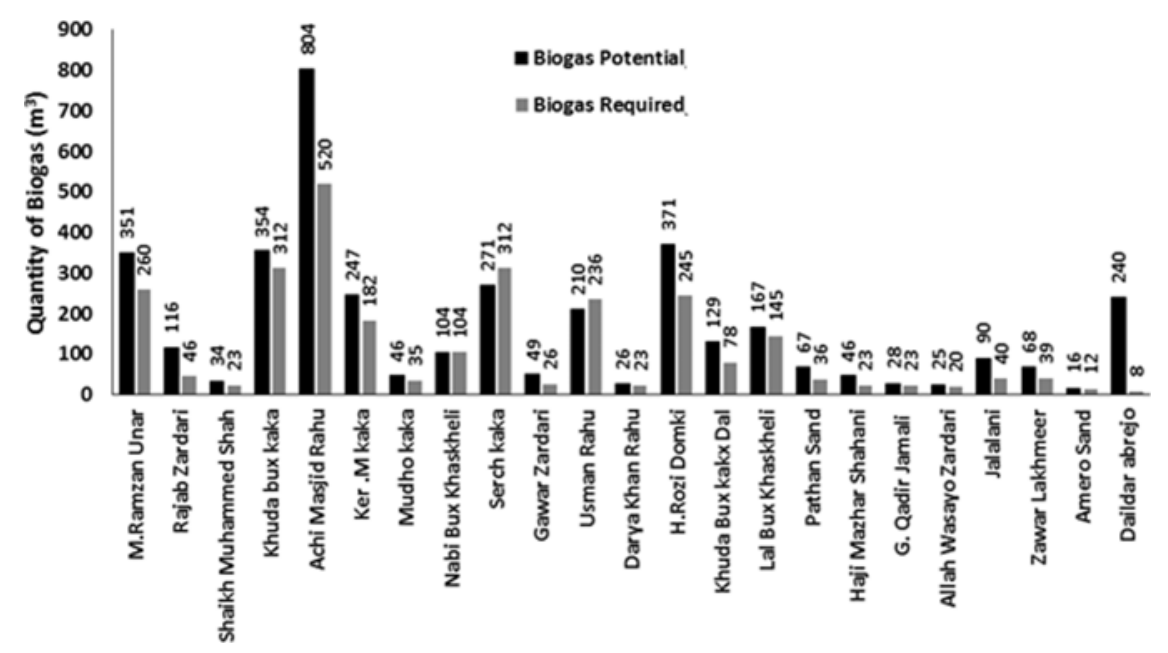

FIG. 6. THE QUANTITY OF BIOGASPOTENTIAL AVAILABLE IN EACH VILLAGE AND REQUIRED BY THE VILLAGERS FOR COOKING 


\subsection{Comparison of Biogas and Traditional Fuel Used in the Villages}

\subsubsection{Health and Environmental Benefits}

The biogas is clean and eco-friendly fuel for cooking [24], while burning of firewood cause lungs and eye diseases in women and children. Additionally, the women spent hours out of home to collect firewood and face a lot of sexual violence problems in Darfur [25]. The biogas potential in the selected villages was estimated as 3859 $\mathrm{m}^{3} /$ day, which can provide health and environmental benefits to the villagers, especially to the women. Moreover, the digested (bio-slurry), which is the byproduct of biogas production is a good organic fertilizer. It increases fertility of soil and ultimately increase the crops production [26-27].

Moreover, the burning of firewood produced $\mathrm{CO}_{2}$ emissions and causes deforestation, indoor air pollution and thus, pollute our environment. The total quantity of the dung consumed by the all selected villages is about 249 tons/month. As per the estimation, burning of one $\mathrm{kg}$ of wood produces about 1.65-1.80 kg of $\mathrm{CO}_{2}$ [28]. By considering the lowest emission rate of $1.65 \mathrm{~kg}$ of $\mathrm{CO}_{2}$ per kg of firewood burnt, and 249 tons of firewood consumption by the selected villages, the annual production of the $\mathrm{CO}_{2}$ was estimated as 4930 tons.

Furthermore, one kg of fresh animal dung emits $0.01 \mathrm{~kg}$ of $\mathrm{CH}_{4}$ [29]. The total amount of animal dung used as the organic fertilizer and dumped in the selected villages was estimated as 89 tons/day, which has the potential to produce 325 thousand tons of $\mathrm{CH}_{4}$ per year. Considering the stoichiometric combustion of $\mathrm{CH}_{4}$ with $\mathrm{O}_{2}$, one $\mathrm{kg}$ of $\mathrm{CH}_{4}$ will produce $2.75 \mathrm{~kg}$ of $\mathrm{CO}_{2}$, thus the equivalent $\mathrm{CO}_{2}$ produced from the animal dung used as the organic fertilizer and dumped in the selected villages will be 893 thousand tons per year. So as the cumulative, if the total quantity of the animal dung produced in the all selected villages is utilized to produce the biogas, then about 900 thousand tons of $\mathrm{CO}_{2}$ emissions could be prevented to contaminate the environment through the global warming.

\subsubsection{Most Suitable Size and Design of the Biogas Plant}

The fixed dome biogas plant is the most suitable biogas plant for villages, as it is simple in design, low cost, high reliability and long life span of 20 years. Regarding the size, the fixed dome biogas plant range from $8-20 \mathrm{~m}^{3}$. The fabrication cost of such plants ranging from Rs. 65000/-

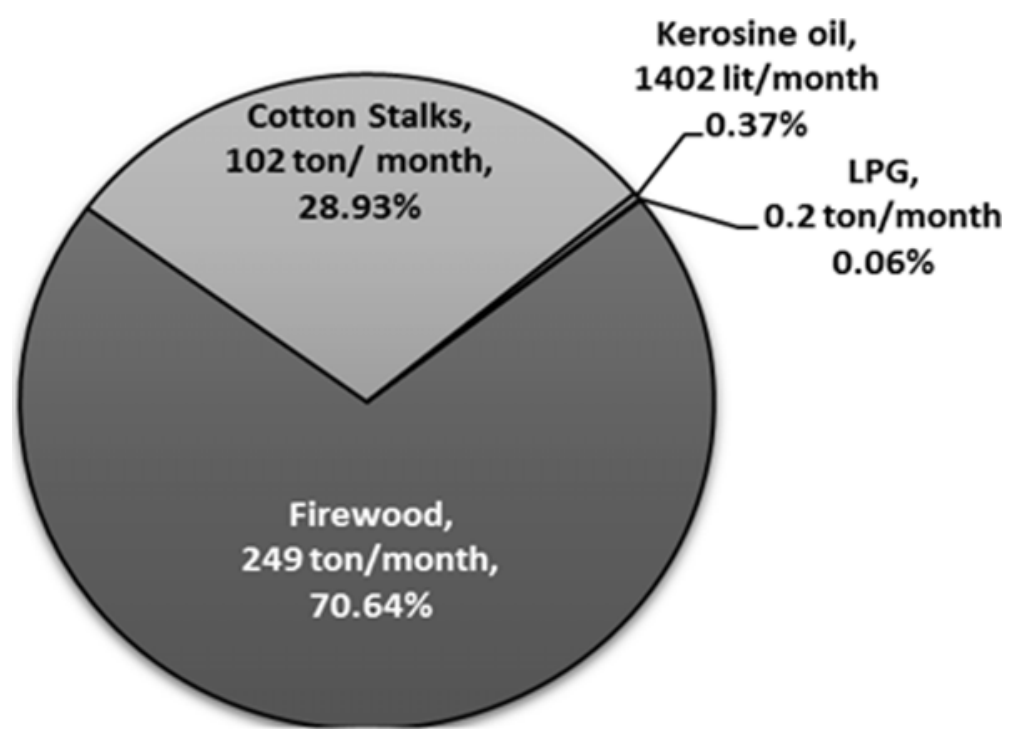

FIG. 7. CONSUMPTION OF ENERGY SOURCES FOR COOKING IN ALL VILLAGES

Mehran University Research Journal of Engineering \& Technology, Volume 36, No. 3, July, 2017 [p-ISSN: 0254-7821, e-ISSN: 2413-7219] 
to Rs. 140,000/- [30]. From the field survey, it was observed that the human population in each house was ranging from 8-10 persons, thus the fixed dome biogas plant of 8$10 \mathrm{~m}^{3}$ is the most suitable for the installation at each house. The design of the fixed dome biogas plant is shown in Fig. 8 [31].

\subsubsection{Economic Benefits}

The economics of the biogas plant starts with the selection of the type of the biogas plant and its capital cost. The economics of the $10 \mathrm{~m}^{3}$ fixed dome biogas plant in comparison to the existing use of the energy for cooking in the selected villages are summarized in Table 1. From the questionnaire data it was estimated that each person consumes about $22 \mathrm{~kg}$ of firewood, $10 \mathrm{~kg}$ of cotton stalks, $0.2 \mathrm{~kg}$ of LPG and 0.25 lit of kerosene oil/month. The local market price of the firewood, cotton stalks, LPG and kerosene oil was Rs. 6/kg, Rs. 0.4/kg, Rs. 110/kg and Rs. 80/ liter, respectively. Thus, the cost of energy/person/month estimated as Rs. 178/-, which will become 19224 rupees for 9 persons in the house in a year. Assuming that the cost of the fixed dome biogas plant is Rs. 100000/-, then the payback period will be approximately 5 years. And as the effective life of the biogas plant is 20 years, thus in remaining 15 years the saving will be about Rs. 285000/-.
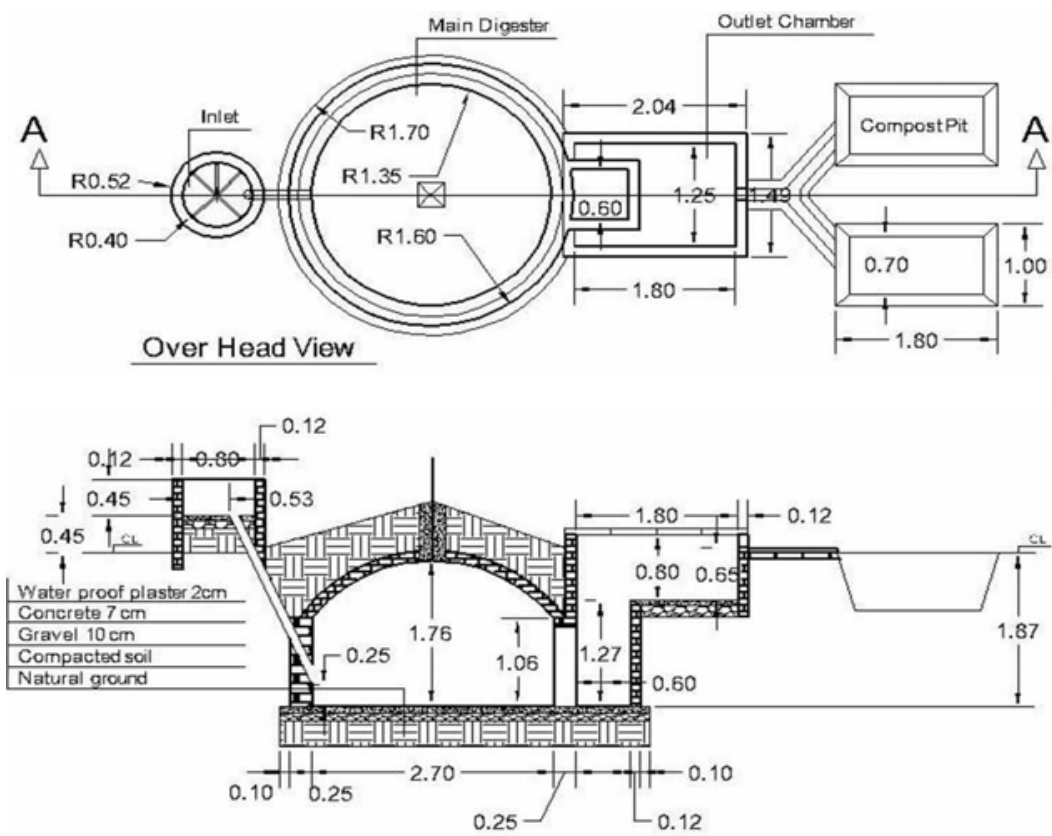

Cross Section A - A

FIG. 8. DESIGN OF MOST SUITABLE SIZED FIXED DOME BIOGAS PLANT FOR THE VILLAGERS OF SAEEDABAD (ALL DIMENSIONS IN M)

TABLE 1. ECONOMICS OF THE $10 \mathrm{M}^{3}$ FIXED DOME BIOGAS PLANT IN COMPARISON TO THE EXISTING USE OF THE ENERGY FOR COOKING

\begin{tabular}{|c|c|c|c|}
\hline Source of Energy & Quantity Used/Person/Month & Rate (Rs.) & Cost (Rs.) \\
\hline Firewood & $22 \mathrm{~kg}$ & $6 / \mathrm{kg}$ & 132 \\
\hline Cotton Stalk & $10 \mathrm{~kg}$ & $0.4 / \mathrm{kg}$ & 4 \\
\hline LPG & $0.2 \mathrm{~kg}$ & $110 / \mathrm{kg}$ & 22 \\
\hline Kerosene Oil & 0.25 lit & 20 \\
\hline \multicolumn{2}{|c|}{ Total cost of energy/person/month (Rs.) } & 178 \\
\hline Total cost of energy for 9 persons/year (Rs.) & 19224 \\
\hline & Capital cost of the biogas plant (Fixed dome) & 100000 \\
\hline Payback period (years) & 5.2 \\
\hline
\end{tabular}

Mehran University Research Journal of Engineering \& Technology, Volume 36, No. 3, July, 2017 [p-ISSN: 0254-7821, e-ISSN: 2413-7219] 
Furthermore, a centralized biogas plant can be installed for all the selected villages. The centralized plant will preferably the combine heat and power unit that will not generate the biogas for cooking and heating, but also generate the electricity.

\section{CONCLUSION}

The area under study was full of animal dung, and there is a serious issue of the management of their dung. Various species of animals (Buffaloes, Cows, Sheep and Goats) are found in the villages of Saeedabad, which produce dung of about 129 tons/day. The produced dung is recommended to be used as the feedstock for domestic biogas plant. The animal dung can be converted into biogas of $3859 \mathrm{~m}^{3}$ per day and a substantial quantity of organic fertilizer. Biogas required by the villagers was $2748 \mathrm{~m}^{3}$ per day. The surplus biogas, which is approximately $1111 \mathrm{~m}^{3}$ can produce electricity of $6666 \mathrm{kWh} /$ day. Furthermore, the produced electricity can fulfill the demand of about half of the population of all villages under study. It is suggested to install a fixed dome biogas plant of size ranging from 8-10 $\mathrm{m}^{3}$. Out of effective life of 20 years of biogas plant the payback period is about five years. It was also observed that the villagers are using firewood, Cotton Stalks, Kerosene Oil and LPG for cooking. The animal dung generated there will not only fulfill energy demand for cooking, but also improve the health of women, the quality of an environment, but also provides employment due to the construction and operation of biogas plants.

\section{ACKNOWLEDGEMENT}

The authors are wishing to acknowledge Mehran University of Engineering \& Technology, Jamshoro, Sindh, Pakistan, for its support to carry out this research work.

\section{REFERENCES}

[1] Imran S., "Evaluating Effectiveness of Biogas Technology and its Effect on Environment. Human Health and Socioeconomic Condition, A Case Study in Sialkot and Narowal District”, M.Phil, Thesis (Environmental Sciences), Lahore School of Economics, Lahore, 2012.

[2] CIA, The World Factbook, https://www.cia.gov/library/ publications/the-worldfactbook/geos/pk.html, (Retrieved $11^{\text {th }}$ January, 2016).

[3] World Wide NGV Statistics NGV Journalhttp:// www.ngvjournal.dreamhosters.com/en/statistics/item/ 911-worldwide-ngv-statistics (Retrieved $2^{\text {nd }}$ February, 2016).

[4] Külling, D.R., Menzi, H., Dohme, F., Sutter, F., Lischer, P., and Kreuzer, M., "Methane Emissions of Differently Fed Dairy Cows and Corresponding Methane and Nitrogen Emissions from their Manure during Storage”, Environmental Monitoring and Assessment, Volume 79, pp. 129-150, 2002.

[5] Abbassi, T., Tauseef, S.M., and Abbasi, S.A., "Biogas and Biogas Energy: An Introduction”, Springer Briefs in Environmental Science, Volume 2, No. 1, 2012.

[6] Brown, V.J., "Biogas a Bright idea for Africa”, Environmental Health Perspectives, Volume 114, No 5, pp. 300-303, 2006.

Pakistan Livestock Census, www.pbs.gov.pk/content/ pakistan-livestock-census-2006 (Retrieved 4th October, 2016).

[8] Prakash, C.G., "Final Report on Technical Study of Biogas Plant Installed in Pakistan”, Asia/Africa Biogas Program Netherlands Development Organization, 2007.

[9] Lassey, K., "Livestock Methane Emission and its Perspective in the Global Methane Cycle”, Australian Journal of Experimental Agriculture, Volume 48, pp. 114-118, 2008. 
[10] Gautum, R., Baralb, S., and Heart, "Biogas a Suitable Energy Sources in Nepal Present Status and Future Challenge”, Renewable, Sustainable Energy Review, Volume, 13, pp. 248-252, 2009.

[11] Ezzati, M., Lopez, A., Rodgers, A., Vander Hoorn, S., and Murray, C., “Comparative Quantification of Health Risks”, Global and Regional Burden of Disease due to Selected Major Risk Factors, Geneva, Switzerland, WHO, pp. 1435-1493, 2004.

[12] Sahito, A.R., Mahar, R.B., Memon, M.A., and Brohi K.M., "Assessment of Waste Agricultural Biomass for Prevailing Management, Quantification and Energy Potential at Sanghar Pakistan”, Waste and Biomass Valorization, Volume 3, pp. 275-284, 2012.

[13] Akinbami, J.F.K., Ilori, M.O., Oyebisi, T.O., Akinwumi, I.O., and Adeoti, O., "Biogas Energy Use in Nigeria”, Renewable and Sustainable Energy Review, Volume 5, pp. 97-112, 2001.

[14] Llori, M.O., Oyebisi T.O., Adekoya L.O., and Adeoti, “Engineering design Nigeria”, Technovtion, Volume 20, pp. 103-108, 2000.

[15] Osuhor, C.U., Alawa, J.P., and Akpa, G.N., "Research note: Manure Production by Goats Grazing Native Pasture in Nigeria”, Tropical Grasslands, Volume 36, pp. 123-125, 2002.

[16] Karttek, D., Chowdhry, V.S., Suresh, J., Punyakumari, B., Dharma Rao, M.V., and Srivani, M., "Potential for Value Addition of Buffalo Dung through Eco-Friendly Disposal in India”, International Research Journal of Environment Science, Volume 3, No. 12, pp. 52-57, 2014.

[17] Vija, V.K., "Integrated Cycle of Cow-Project for Rural Self Sustainable Economic Development”, Centre for Rural Development and Technology, Indian Institute of Technology Hauz Khas, New Delhi, 2006.
[18] NERC, Manure Generation Calculator, https://nerc.org/ documents/manure.../manure_generation_calculator.xl. (Retrieved 8th January, 2016)

[19] Afzal, M., and Naqvi, A.N., "Livestock Resources of Pakistan: Present Status and Future Trends”, Quarterly Science Vision, Volume 9, pp. 1-2, 2003-4.

[20] Ahmad, S., "Energy and Bio-Fertilizers for Rural Pakistan”, Opportunities, Integrated Technology Applications, Vision and Future Strategy Managing Natural Resources for Sustaining Future Agriculture Research Briefings, Volume 2, No. 17, 2010.

[21] Nation Master http://www.nationmaster.com/graph/ ene_ele_con_percap-energy electricity-consumptionper-capita. (Accessed 4th October, 2016).

[22] Fox, J., "Firewood Consumption in a Nepali Village", Environmental Management, Volume 8, No. 3, pp. 243-250, 1984.

[23] Bhatt, B.P., and Sachin, M.S., "Firewood Consumption Pattern of Different Tribal Communities in North East India”, Energy Policy, Volume 32, pp. 1-6, 2004.

[24] Ndinechi, M.C., Onwusuru, I.M., and Ogungbenro, O.A., "Academic Research Economic Potentials of Animal Dung as A Viable Source of Biomass Energy”, International [ISSN-L: 2223-9553, ISSN: 2223-9944], Volume 2, No. 1, 2012.

[25] Patrick, E., "Sexual Violence and Firewood Collection in Darfur”, Force Migr Review, volume 27, pp. 40-1, 2007.

[26] Sagagi, B., Garba, and Usman, N.S., "Studies of Biogas Production from Fruits, Vegetables and Cow Dung”, Bayero Journal of Pure and Applied Sciences, Volume 2, No. 1, pp.115-118, 2009.

[27] Bonten, L.T.C., Zwart, K.B., Rietra, R.P.J.J., Postma, R., and de Haas, M.J.G., "Bio-Slurry as Fertilizer is BioSlurry from Household Digesters a Better Fertilizer than Manure? A Literature Review”, Wageningen, Alterra Wageningen UR, University \& Research Centre, Alterra Report 2519, pp. 46, 2014. 
[28] Wah, L.C., "The Study on Indoor Environmental Quality and Effectiveness of Adopting Shera Instead Using Timber as Sustainable Building Material in Kampong Villa, Palau Banding”, Asian Architecture [ARC 2234/ ARC 60403], 2015.

[29] Raymond, M., "Environmental, Social and Other Positive Impacts of Building Household Biogas Plants in Rural India”, World Council for Renewable Energy and EUROSOLAR, Sponsored Second World Renewable Energy Forum: Renewing Civilization by Renewable Energy, pp. 1-17, 2004.
[30] Khurshid, M., "Biogas Development in Rural Areas of Pakistan: A Sustainable Option for Domestic Energy”, A Scientific journal of COMSATS - Science Vision, Volume 15, No 2, pp. 57-61, 2009.

[31] Mears E.T., and Anderson R.H., "Biogas Plant Construction Manual”, United States Forces Afghanistan”, Joint Engineer Directorate Kabul, Afghanistan, pp. 23, April, 2011. 